YOUTH, POPULAR CULTURE AND MORAL PANICS 


\title{
Youth, Popular Culture ANd Moral Panics
}

\section{Penny Gaffs to Gangsta-Rap, 1830-1996}

\author{
John Springhall \\ Reader in History \\ University of Ulster at Coleraine
}

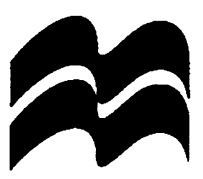


(C) John Springhall 1998

Softcover reprint of the hardcover 1st edition 1998

All rights reserved. No reproduction, copy or transmission of this publication may be made without written permission.

No paragraph of this publication may be reproduced, copied or transmitted save with written permission or in accordance with the provisions of the Copyright, Designs and Patents Act 1988, or under the terms of any licence permitting limited copying issued by the Copyright Licensing Agency, 90 Tottenham Court Road, London W1P 9HE.

Any person who does any unauthorised act in relation to this publication may be liable to criminal prosecution and civil claims for damages.

The author has asserted his right to be identified as the author of this work in accordance with the Copyright, Designs and Patents Act 1988.

First published 1998 by

MACMILLAN PRESS LTD

Houndmills, Basingstoke, Hampshire RG21 6XS

and London

Companies and representatives throughout the world

ISBN 978-0-333-66083-6

ISBN 978-1-349-27458-1 (eBook)

DOI 10.1007/978-1-349-27458-1

A catalogue record for this book is available from the British Library.

This book is printed on paper suitable for recycling and made from fully managed and sustained forest sources.

$\begin{array}{llllllllll}10 & 9 & 8 & 7 & 6 & 5 & 4 & 3 & 2 & 1\end{array}$

$\begin{array}{llllllllll}07 & 06 & 05 & 04 & 03 & 02 & 01 & 00 & 99 & 98\end{array}$

Published in the United States of America 1998 by

ST. MARTIN'S PRESS, INC.,

Scholarly and Reference Division,

175 Fifth Avenue, New York, N.Y. 10010

ISBN 978-0-312-21394-7 cloth

ISBN 978-0-312-21395-4 paperback 
For the members of the south-west London Gastronomico-Philosophical Society - IN VINO VERITAS 


\section{CONTENTS}

Acknowledgements

viii

Introduction

1 Penny Theatre Panic: Anxiety over Juvenile Working-class Leisure

2 'Penny Dreadful' Panic (I):

Their Readers, Publishing and Content

3 'Penny Dreadful' Panic (II): Their Scapegoating for Late-Victorian Juvenile Crime

4 Gangster Film Panic: Censoring

Hollywood in the 1930 s

5 'Horror Comic' Panic: Campaigning

against Comic Books in the 1940s and 1950s

6 Mass Media Panic: The 1980s and 1990s

Conclusions

Appendix I Jack Sheppard in Victorian Popular Culture

Appendix II American Dime and Half-Dime Novels

Appendix III Hank Janson Paperbacks of the 1950s

Notes

Bibliography

Index 


\section{ACKNOWLEDGEMENTS}

I owe a great deal to archivists and librarians for making documents and collections relevant to my research into theatrical, literary, cinematic and comic-book history available and, in most cases, allowing generous photocopying. Special thanks to Clive Hurst, Head of Special Collections at the Bodleian Library, Oxford, for allowing access to 'penny dreadfuls' held in the Opie, John Johnson, and Frank Pettingell Collections. The following libraries and museums also helped with access to special collections used for Chapters 2 and 3: the Boys and Girls House (Osborne Collection) of Toronto Public Library; the Walter Library (Hess Collection) of the University of Minnesota in Minneapolis; the Rare Books Section (Dime Novel Collection), Library of the University of Rochester, New York State; the British Library (Barry Ono Collection); and the Bethnal Green Museum of Childhood (Renier Collection), London. Chapters 1-3 could not have been written without access to the British Newspaper Library in Colindale, London. Russ Cochran of West Plains, Missouri, deserves mention for publishing the unique EC comic-book series once again. Chapter 4 on gangster films would not have been possible without access to the British Film Institute Library in London. Research for Chapter 5 was carried out at the Library of Congress in Washington. Frequent resort was also made to Cambridge University Library, unrivalled as a copyright library with an excellent cafeteria attached. The inter-library loan service of my employer, the University of Ulster at Coleraine, has proved invaluable on the remote periphery and I am grateful to the Faculty of Humanities for granting me periods of study leave and for assisting with travel expenses to the above libraries. I hope the reader will find what follows as pleasurable to read, despite the prosy academic style, as it has been to research.

Distinguished past and present Ulster colleagues, Sean Connolly, Bill Riches, David Pattie, Wally Johnson, Terry O'Brien and Steve Ickringill, kindly read and commented upon drafts which have subsequently made up the chapters of this book. The final stage of preparing the typescript was expedited by Gillian Coward, Rafik L. Mortada, and Joanne Taggart. 
The editors of the following journals have given me permission to incorporate in revised form some previously published material: The Economic History Review, Victorian Studies, History Today, History of Education and Victorian Periodicals Review. The Editors of the proceedings of the 1980 and 1994 annual conferences of the History of Education Society of Great Britain have also given permission to reproduce copyright material.

I have had the great privilege in recent years of trying out some of my ideas in papers given to the Queen's Cultural Forum in Belfast, the History of Education Society, the Victorian Periodicals Society and to Popular Culture Association conferences in both America and England. Research on 'penny dreadfuls' brought me into contact with Kevin Carpenter, Michael Holmes and Mike Saavedra, collectors who are also serious students of the literature. I am indebted for the conversation and companionship of those to whom this book is dedicated, the Colcloughs, the Fishers, the Roberts and the Mazlins, without whom my research sojourns in London would have been much duller. I am also grateful for the long-term support of both my mother and brother. Final-year students taking thematic modules at the University of Ulster at Coleraine on 'Popular Culture' or, more recently, 'Leisure, Sport and the Media', may have wondered over the years why they were hearing so much about the 'penny dreadful'. This book should explain that preoccupation and I am grateful for their forebearance.

Portstewart JoHn SPRINGHALL

Co. Londonderry

Northern Ireland 